\title{
FLOWERS, FRUITS, AND THE ABUNDANCE OF THE YELLOW-CHEVRONED PARAKEET (Brotogeris chiriri) AT A GALLERY FOREST IN THE SOUTH PANTANAL (BRAZIL)
}

\author{
RAGUSA-NETTO, J. \\ Departamento de Ciências Naturais, Campus Três Lagoas, UFMS, C.P. 210, \\ CEP 79600-000, Três Lagoas, MS, Brazil \\ Correspondence to: José Ragusa-Netto, Departamento de Ciências Naturais, Campus Três Lagoas, UFMS, \\ C.P. 210, CEP 79600-000, Três Lagoas, MS, Brazil, e-mail: forpus@ceul.ufms.br \\ Received July 10, 2003 - Accepted October 7, 2003 - Distributed November 30, 2004
}

(With 3 figures)

\begin{abstract}
Parakeets usually forage for massive and ephemeral plant resources at forest canopies. Fruit pulp is widely cited as a major food resource for these birds, which often eat seeds and nectar. In this study, I assessed flower and fruit production at a gallery forest in the Pantanal flood plain (Brazil) in order to evaluate the relationship between food resource production and abundance of a common parakeet, Brotogeris chiriri. Also, I evaluated the relationship between food resource production and foraging activity. Parakeet abundance varied markedly along the year, coinciding with massive episodes of flower and fleshy fruit availability. Inga vera nectar, intensely used during the latter part of dry season, was by far the most exploited food item by parakeets when they were very abundant. The nectar comprised $34 \%$ of the parakeets' diet $(\mathrm{N}=131$ feeding records) at the gallery forest, while fleshy fruits made up the rest. Parakeets principally exploited fruits of Cecropia pachystachya and Ficus luschnathiana, besides palm fruits and Inga vera arils. The consistent relationship between foraging activity and parakeet abundance, as well as the coincidence between fluctuations of these parameters and availability of major food resources, suggests that food availability mostly influenced $B$. chiriri occurrence in the gallery forest. Furthermore, I found no evidence for gallery forest use for roosting and/or breeding, in spite of the fact that such factors usually influence local parakeet abundance.
\end{abstract}

Key words: Psittacidae, Brotogeris, feeding ecology, gallery forest, Pantanal.

\section{RESUMO}

\section{Flores, frutos e abundância do periquito-de-asa-amarela (Brotogeris chiriri) em uma mata ciliar do Pantanal Sul (Brasil)}

Periquitos normalmente exploram recursos massivos e efêmeros no dossel das florestas tropicais. Dentre os itens alimentares mais utilizados está a polpa de frutos, embora sementes e néctar também sejam consumidos. Neste estudo, foi avaliada a produção de flores e frutos em uma mata ciliar do Pantanal (Brasil) e sua relação com a abundância do periquito Brotogeris chiriri. Além disso, avaliaram-se as relações entre a produção de flores e frutos e o padrão de exploração desses recursos alimentares. A abundância dos periquitos variou profundamente ao longo do ano, coincidindo com a oferta massiva de flores e de certos frutos carnosos. O néctar das flores de Inga vera foi amplamente consumido no final da estação seca e, de longe, o recurso mais explorado quando os periquitos eram abundantes, correspondendo a $34 \%$ da dieta $(\mathrm{N}=131$ registros de alimentação), enquanto o restante era de frutos carnosos. Os periquitos consumiram substancialmente os frutos de Cecropia pachystachya e Ficus luschnathiana, além de frutos de palmeiras e arilos das sementes de I. vera. A relação entre a abundância dos periquitos e o respectivo padrão de utilização dos recursos alimentares, bem como as coincidências entre as flutuações desses parâmetros com a oferta dos recursos alimentares mais explorados, sugerem que flores e frutos causaram as variações no número de periquitos na mata ciliar. Apesar de os psitacídeos utilizarem regularmente certos ambientes como dormitórios coletivos ou sítios de 
reprodução, não foram encontradas evidências quanto à influência desses locais na abundância dessas aves na mata ciliar.

Palavras-chave: Psittacidae, Brotogeris, ecologia alimentar, mata ciliar, Pantanal.

\section{INTRODUCTION}

Psittacidae is among the most diverse neotropic bird groups, including a gradient of forms from small parrotlets (Forpus, 25-30 g) up to the largest macaws (Anodorhynchus, over $1 \mathrm{~kg}$ ). In addition, such primary consumers usually occur in large population whose members have no all-purpose territories; hence, they are likely to wander in flocks over large areas (Casagrande \& Beissinger, 1997; Gilard \& Munn, 1998). Parrots live in a wide range of habitats, from dry semi-open country to tall rainforests (Forshaw, 1989) but, in fact, they usually exploit a variety of vegetation types that compose a given area (Casagrande \& Beissinger, 1997; Gilard \& Munn, 1998; Renton, 2001). Living in heterogeneous habitats, many parrot species use a diverse set of ephemeral and unpredictable food resources, as the result of a flexible diet that may include from nectar to hard seeds (Roth, 1984; Renton, 2001). Nevertheless, some large parrots specialize in a few asynchronously-produced fruit types, such as palm fruits (Roth, 1984; Sick, 1997; del Hoyo et al., 1997).

Generally, neotropical areas are markedly seasonal, with evident flowering and fruiting pulses interspersed with periods of extreme scarcity (Terborgh, 1986; van Shaick et al., 1993). Hence, frugivorous/granivorous birds such as parrots need to move among habitats, searching for food patches (Wirminghaus et al., 2001, 2002; Renton, 2001). Since they use flowers and fruits as these become available, their diet may follow a highly seasonal pattern, mainly in dry habitats (Galetti, 1993; Wermundsen, 1997; Renton, 2001).

The genus Brotogeris includes small and highly abundant neotropical parakeets, widespread over a wide range of habitats from dry savannas to rainforests (del Hoyo et al., 1997). Such parakeets usually feed on soft and sweet fruit pulp, but also forage for diverse items such as nectar and seeds (Roth, 1984; Pizo et al., 1995; Galetti, 1997; RagusaNetto, 2002a,b). In consuming these various resources they pollinate some tree species (Vicentini \& Fischer, 1999; Cotton, 2001) but, conversely, in drinking the nectar they destroy much of the flower crops (Cotton, 2001; Ragusa-Netto, 2002a). They are also important seed predators (Janzen, 1981; Francisco et al., 2002; Ragusa-Netto, 2002b). However, basic data on their pattern of abundance and feeding ecology are as yet poorly researched (but see Roth, 1984; Pizo et al., 1995; Galetti, 1997; Gilardi \& Munn, 1998).

The yellow-chevroned parakeet (Brotogeris chiriri) is among the most abundant and widespread South American parrots (Forshaw, 1989). It is particularly abundant in the interior of Brazil and widely cited as common along watercourses (del Hoyo et al., 1997). However, the factors related to $B$. chiriri occurrence in the gallery forests are unclear. As parakeets heavily rely on plant food resources, evaluating their responses to variations in the food supply may clarify the role of such factors in local patterns of abundance, especially in seasonal habitats with marked pulses of plant resource production (van Schaik et al., 1993). Thus, in this study I assessed the abundance of $B$. chiriri at a gallery forest in the highly seasonal Pantanal (Brazil), as well as flower and fruit production, in order to evaluate the relationship between these parameters. Also, I examined B. chiriri foraging activity to analyze the relationship between both resource and parakeet abundance, and food resource use.

\section{METHODS}

\section{Study area}

This study was developed in the South Pantanal flood plain at the gallery forest of the Miranda River (municipality of Corumbá, Mato Grosso do Sul State, $19^{\circ} 35^{\prime} \mathrm{S}, 57^{\circ} 2.0^{\prime} \mathrm{W}$, altitude $\pm 100 \mathrm{~m}$ ). The vegetation in the area is a mosaic composed of palm savanna (Copernicia alba), tecoma savanna (Tabebuia aurea), patches of deciduous forest interspersed with open grassy areas, and the dense Miranda river gallery forest. This forest is 50-200 m wide, with an 8-13 $\mathrm{m}$ canopy, but emergent trees may reach $17 \mathrm{~m}$. From July to September many tree species drop their leaves, although abundant evergreen species such as Inga vera and Ocotea diospyrifolia contribute to an evident semi-deciduous pattern. Common tree species are Inga vera, Ocotea diospyrifolia, Tabebuia heptaphylla, Vitex cymosa, Cecropia pachystachya, 
Genipa americana, Sapium obovatum, and Banara arguta. Annual rainfall is around $1,000 \mathrm{~mm}$, most of which occurs from November to March (wet season). In this period average temperature is $27^{\circ} \mathrm{C}$, while in the dry season (April to October) average temperature is $20^{\circ} \mathrm{C}$; in the coldest months (JuneJuly) frosts may occur. In this area of the Pantanal, inundation pulses typically occur from January to March. During floods, the water level in the gallery forest may rise to $1.5 \mathrm{~m}$ (Fig. 1).

\section{Flower and fruit abundance}

In order to sample flower and fruit production, phenology transects (a total of $5 \mathrm{~km}$ ) were established in four tracts (400-800 m apart) of gallery forest. In this habitat, topography and drainage are not uniform and neither is the effect of floods. Consequently, due to the patchy occurrence and/ or distribution of tree species (Oliveira-Filho et al., 1990, 1994), I randomly positioned (parallel to the water course) continuous $300 \mathrm{~m}$ transect segments from the river $(5 \mathrm{~m}, 35 \mathrm{~m}, 65 \mathrm{~m}$, and $95 \mathrm{~m})$ to the proximity of the forest edge. Along these trails, a total of 370 trees were numbered with aluminum tags. Trees were selected if they were located within a $2.0 \mathrm{~m}$ band on either side of the trails and their diameter at breast height (DBH) was equal to, or greater than $30 \mathrm{~cm}$. This criterion was adopted to assure the inclusion of canopy and emergent trees in the sample, since parakeets typically forage on the canopy. Also, a tree was selected only if at least 80 percent of the crown could be observed from the forest floor. This random sample included 29 tree species, of which there was no prior knowledge about their importance for $B$. chiriri. Using $8 \times 40$ binoculars, individual crowns were monitored monthly (between days 5 and 10, from April 2000 to March 2002) for the presence of flowers and fruits. The abundance of flowers as well as unripe and ripe fruits was noted and ranked on a relative scale ranging from total absence to the full crown capacity of a given phenophase (0 to 4; Fournier, 1974). Thus, the monthly index of resource abundance of a given phenophase resulted from the sum of all abundance scores. Tree species were identified by comparison with samples in the herbarium at the Universidade Federal do Mato Grosso do Sul (Corumbá campus) and following Pott \& Pott (1994). Analysis of dispersal syndromes was out of the scope of this study, hence the fruits were classified only according to the presence of fleshy edible parts, instead of dispersal features (zoochory, autochory, and anemochory). Thus, tree species whose dyaspores include pulp or aril were considered species with fleshy fruit, whereas those with dry mesocarp were regarded as species with dry fruits.

\section{Parakeet abundance}

To sample $B$. chiriri abundance, point count was used since this is a suitable technique for studies on parrot abundance in closed habitats (Casagrande \& Beissinger, 1997; Marsden, 1999). In the routes established for phenology studies, I positioned 18 points (300 $\mathrm{m}$ apart from each other) from which parakeets were counted. Parakeets were counted monthly during three mornings (six point/morning; between days 5 and 10) without rain or heavy mist. At each point all B. chiriri seen or heard during 10 min were recorded irrespectively of the distance from the census station. All census work was carried out in the dry season from 6:30 $\mathrm{h}$ to approximately 8:30 $\mathrm{h}$, and from 6:00 $\mathrm{h}$ to $8: 00 \mathrm{~h}$ in the wet season. The parakeets observed and/or heard flying by over the gallery forest (parakeets calling continuously from different positions while detected above the canopy) were not recorded, since the closed canopy made it difficult to follow them until they landed on a specific vegetation type.

\section{Parakeet resource use}

To sample the consumption of flowers and fruits by $B$. chiriri, direct observations of feeding activity were carried out. Every month the trails designated to sample both parakeet and resource abundance were walked ( $30 \mathrm{~h} /$ month) from 6:00 to 11:00 $\mathrm{h}$ and from 15:00 to $18: 00 \mathrm{~h}$, when parakeets were usually foraging. Whenever at least a feeding parakeet was detected, I recorded: a) tree species; b) food resource (flower or fruit); c) part eaten (petal, nectar, pulp, or seed); d) the number of parakeets foraging; and e) the time and date. Thus, a feeding record consisted of at least one parakeet feeding on a food resource, regardless of time spent foraging and food amount ingested. As feeding records were used in correlation analyses, I used only the initial observation to assure independence among foraging samples. Moreover, as the bulk of the neotropical parrot diet includes massive resources, the use of initial observation is suitable, since parakeets foraging on such abundant food items, in principle, are equally likely to be sampled due to their similar conspicuousness (Hejl et al., 1990). 


\section{Analyses}

The number of $B$. chiriri recorded monthly from the 18 points was taken as a monthly index of parakeet abundance. To evaluate the relationship between parakeet abundance and food resource production, the Spearman correlation was used, with monthly indexes of both resource and parakeet abundance taken as variables. The relationship between parakeet abundance and foraging activity, as well as the relationship between resource availability and foraging activity was also evaluated through correlation analysis. The monthly percentage of feeding records was taken as an index of foraging activity and correlated (Spearman correlation) both with resource and parakeet abundance.

\section{RESULTS}

\section{Flower and fruit production}

The 29 tree species recorded in the phenology transects belong to 18 families. Most species (66\%) and trees $(80 \%, \mathrm{~N}=370$ trees) produced fleshy fruits, while only 10 species and 76 trees produced dry fruits. Among the most common species were Inga vera (66 trees), Ocotea diospyrifolia (62), Vitex cymosa (43), Tabebuia heptaphylla (36), Cecropia pachystachya, and Genipa americana (both 24 trees). Annually, flower production occurred conspicuously twice, first in the middle of dry season, mainly as the result of flowering of Tabebuia heptaphylla and Ocotea diospyrifolia, and a later, very pronounced flowering peak during the transition from dry to wet season (Figs. 1 and 2). Such massive flower production resulted from flowering in Vitex cymosa, Cecropia pachystachya, and Genipa americana, besides the highly abundant Inga vera, whose intense flowering lasted for two months in both years (Fig. 2). Another, but slight, flower peak resulted from flowering in species (mainly Banara arguta and Sapium obovatum) often exposed to floods for longer periods. Flowering in these species was marked during February 2001 (the latter part of wet season), but less evident in the same period in 2002 (Fig. 2).

Fruiting pattern included two annual evident peaks. The first and very pronounced fruiting peak occurred during the middle of the wet season (December-February; for unripe fruits, the peaks occurred a month earlier), while the other happened in the transition from the wet to the dry season (MarchMay; Fig. 2). Massive fruit production during the middle of the wet season resulted mainly from fruiting of Vitex cymosa, Ocotea diospyrifolia, and Cecropia pachystachya. However, in the second studied year Ocotea diospyrifolia produced no fruits, and Cecropia pachystachya bore fruits later. Thus, the large fruit crop of Vitex cymosa accounted for most of the fruit production in this period (Fig. 2). The fruit production peak in the transition from the wet to the dry season was generated by fruiting of Banara arguta, Sapium obovatum, Crataeva tapia, Copernicia alba, and Inga vera. The latter, despite massive flowering, generally had a small fruit crop, while Banara arguta and Sapium obovatum bore a very large fruit crop, which was particularly important for this fruiting peak, which included ripe fruits simultaneously with floods.

Brotogeris chiriri food resources use Parakeets foraged on 12 tree species from eight families (Table 1). They substantially exploited species from only four families, of which parakeets ate different items. Arecaceae parakeets used the fruit pulp, those of Cecropiaceae and Moraceae consumed pulp and small seeds, and Leguminosae parakeets exploited nectar and arils (Table 1). Although parakeets mostly used fruit pulp/aril from several tree species $(66 \%$ of feeding records, $\mathrm{N}=$ 131), Inga vera nectar comprised the bulk of nectar consumed ( $29 \%$ of $34 \%$ of the feeding records), in addition to which a very large number of individuals foraged for this item (Table 1). However, if the analysis of nectar use was limited to the later dry season when fleshy fruits were scarce (Figs. 2 and 3 ), their proportional use was higher, corresponding to $50 \%$ of feeding records $(\mathrm{N}=16)$ during the later dry season of 2000, while in the same period in 2001 this item accounted for all feeding records $(\mathrm{N}=22$, Fig. 3).

In the course of the dry season figs were an important resource for parakeets, in spite of the fact that only a few (but very large) trees are found in the forest tracts sampled. Fig trees bore fruits both in the wet and dry seasons, but most feeding records including figs occurred during the dry season $(70 \%$, $\mathrm{N}=16$ ). From the early to middle dry season (mainly April and May), B. chiriri foraged mostly for palm fruits. Copernicia alba bore ripe fruits only in this period, while Attalea phalerata produced fruits year round. Particularly in May 2001 parakeets foraged almost only for palm fruits, since $50 \%$ of the feeding records corresponded to Copernicia alba fruits, while fruits of Attalea phalerata amounted to $36 \%$ of feeding records $(\mathrm{N}=22)$. 


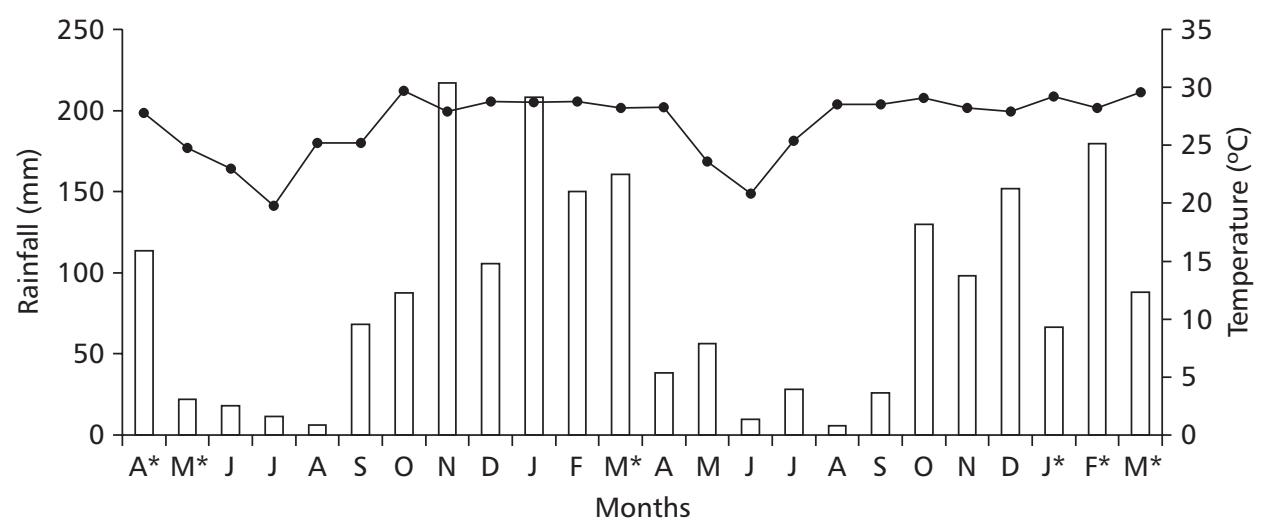

Fig. 1 - Monthly rainfall (columns), and average temperature (line) in the South Pantanal, from April 2000 to March 2002. Asterisk denotes flood period.
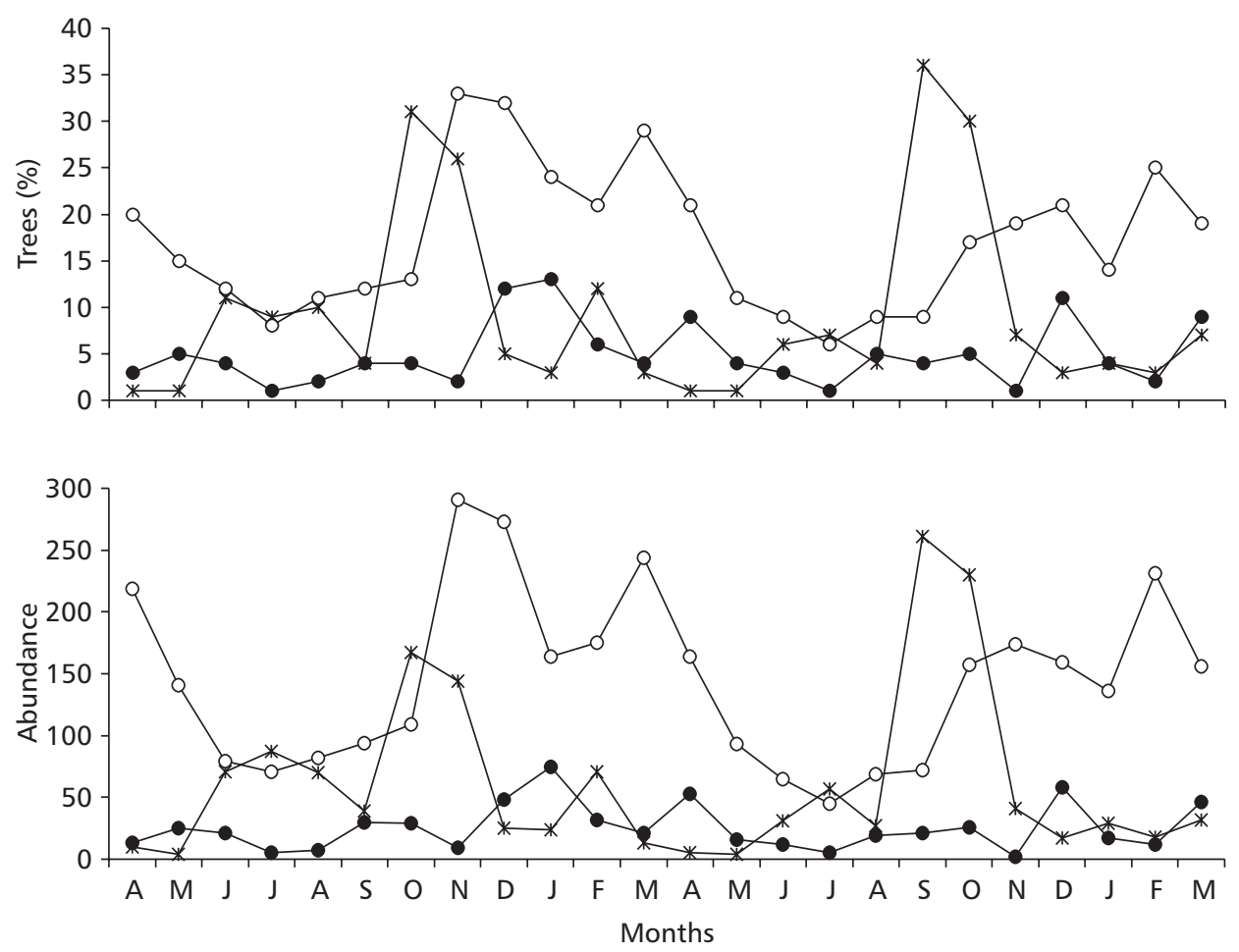

Fig. 2 - Percentage of flowered trees (asterisk, $\mathrm{N}=370$ ), trees bearing immature (open circle) and mature fruits (full circle), as well as the abundance of these resources at the Miranda river gallery forest from April 2000 to March 2002. 
TABLE 1

Plant species monthly used by Brotogeris chiriri $(\mathrm{N}=131$ feeding records) and parakeets recorded foraging at the Miranda river gallery forest (South Pantanal).

\begin{tabular}{|c|c|c|c|c|}
\hline Family/Species & Item* & Month & $\begin{array}{c}\text { Feeding } \\
\text { records }(\%)\end{array}$ & Parakeets \\
\hline Arecaceae/Copernicia alba & $\mathrm{p}$ & Apr., May & 7.0 & 26 \\
\hline Arecaceae/Attalea phalerata & $\mathrm{p}$ & $\begin{array}{c}\text { Jan., Feb., Apr., May., } \\
\text { Jun., Jul., Aug., Sept., } \\
\text { Oct., Dec. }\end{array}$ & 10.0 & 25 \\
\hline Bignoniaceae/Tabebuia heptaphylla & $\mathrm{f}$ & Aug. & 1.0 & 3 \\
\hline Capparidaceae/Crataeva tapia & $\mathrm{p}$ & Feb. & 1.0 & 2 \\
\hline Cecropiaceae/Cecropia pachystachya & $\mathrm{p}, \mathrm{s}$ & $\begin{array}{l}\text { Dec., Jan., Feb., } \\
\text { March }\end{array}$ & 17.0 & 61 \\
\hline Flacourtiaceae/Banara arguta & $\mathrm{p}, \mathrm{s}$ & Apr. & 2.0 & 4 \\
\hline Leguminosae/Erythrina fusca & $\mathrm{f}$ & Sept. & 1.0 & 1 \\
\hline Leguminosae/Inga vera & $\begin{array}{l}\mathrm{n} \\
\mathrm{a}\end{array}$ & $\begin{array}{c}\text { Aug., Sept., Oct., Nov., } \\
\text { Feb., March., Apr. }\end{array}$ & $\begin{array}{l}29.0 \\
12.0\end{array}$ & $\begin{array}{c}188 \\
49\end{array}$ \\
\hline Leguminosae/Lonchocarpus sericeus & $\mathrm{n}$ & March & 1.0 & 10 \\
\hline Moraceae/Ficus luschnathiana & $\mathrm{p}, \mathrm{s}$ & Jun., Sept., Oct., Dec. & 12.0 & 64 \\
\hline Verbenaceae/Vitex cymosa & $\begin{array}{c}\mathrm{f} \\
\mathrm{p}, \mathrm{s}\end{array}$ & Oct., Dec., Jan. & $\begin{array}{l}2.0 \\
3.0\end{array}$ & $\begin{array}{c}3 \\
13\end{array}$ \\
\hline Viscaceae/Phoradendron affine & $\mathrm{p}, \mathrm{s}$ & May & 2.0 & 16 \\
\hline
\end{tabular}

* Item used: $\mathrm{a}=$ aril, $\mathrm{n}=$ nectar, $\mathrm{f}=$ flower, $\mathrm{p}=$ pulp, $\mathrm{s}=$ seed.

During the wet season parakeets conspicuously consumed fruits of the abundant Cecropia pachystachya, which also fruited during the dry season, but were not used at that time. From December to March parakeets disproportionately foraged for these fruits (46\% of feeding records), in spite of the usual, plentiful fleshy fruit availability during the rainy season (Fig. 3). In the transition from the wet to dry seasons (March and April) parakeets mostly used Inga vera arils, which made up $60 \%$ of the feeding records $(\mathrm{N}=18)$.

Brotogeris chiriri abundance - Parakeet abundance fluctuated markedly along the year, with their occurrence in the gallery forest particularly pronounced during the later dry (every year) and later wet seasons (mainly 2002). Conversely, from the early to middle dry season only few or even no parakeets were recorded (Fig. 3). These major peaks of parakeet abundance coincided with massive flowering in the later dry season and fruiting in the transition from the wet to dry season (flood period). A very large number of parakeets foraged for nectar during the massive flowering, hence their abundance was consistent with the use of an important food resource. However, the general pattern of flower production was unrelated to fluctuations of parakeet abundance ( $r s=0.10, p=0.63$, Fig. 3). Feeding records indicated a preponderance of fleshy fruits $(66 \%)$. Nevertheless, important items such as figs and palm fruits (Attalea phalerata) were produced asynchronously, and parakeets least used most of the fleshy fruits available during rains. In addition, Inga vera and Cecropia pachystachya fruits were available mainly during the later wet season in 2002 (Fig. 3). Thus, fluctuations in fleshy fruit production were not related to the variations in parakeet abundance ( $r s=0.18, p=0.40$, Fig. 3). Also, even if combined, flower and fleshy fruit availability were unrelated to parakeet abundance (multiple regression, $\mathrm{R}=0.30, \mathrm{p}=0.15$ ). On the other hand, most parakeets foraged in the gallery forest for massive resources available mainly from later in the dry to later in the wet season, while parakeets were almost absent from the gallery forest during most of the 
dry season, when resources were scarce. Hence, the significantly correlated to variation in abundance variations in parakeet foraging activity were $(\mathrm{rs}=0.50, \mathrm{p}<0.05$, Fig. 3).
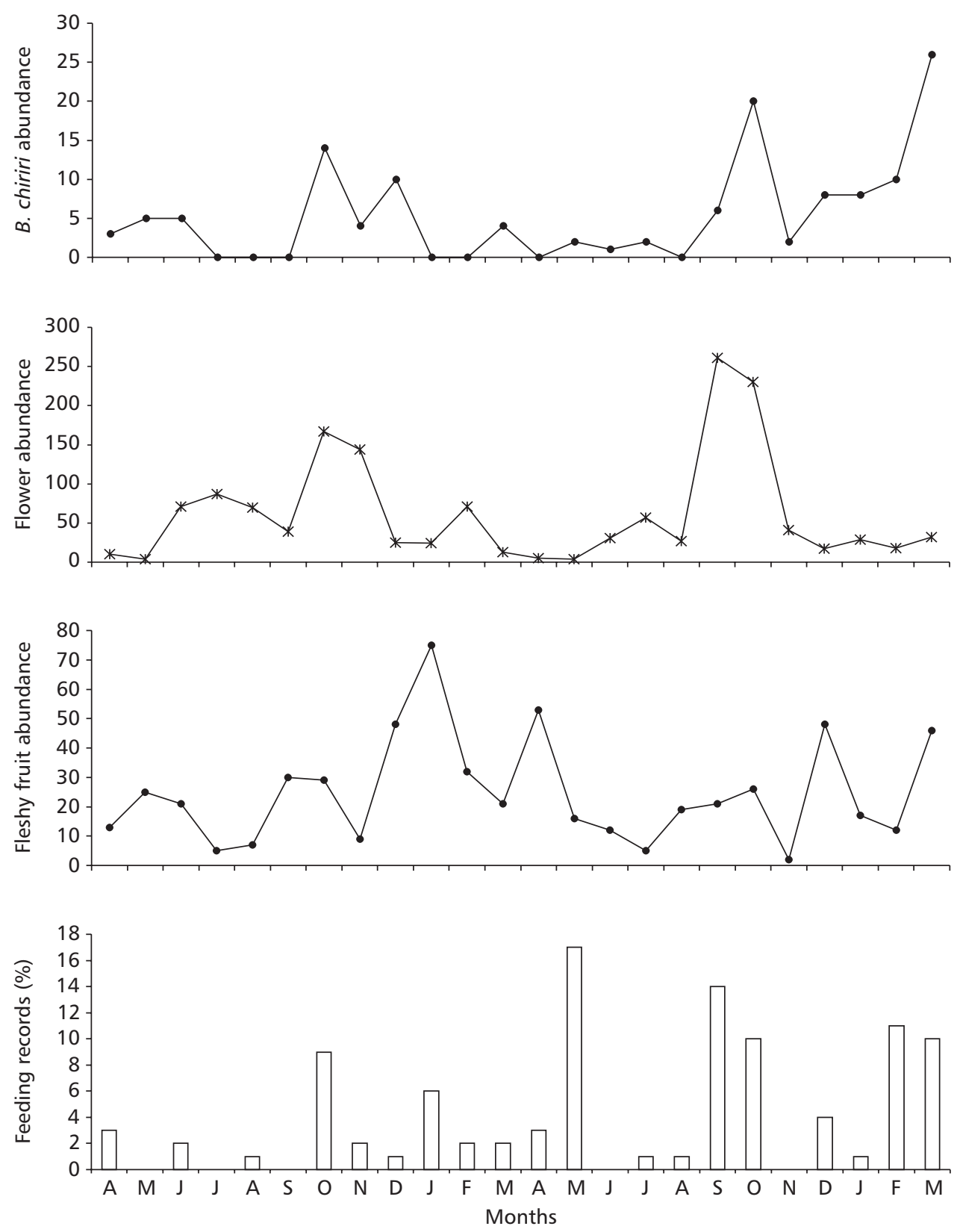

Fig. 3 - From top to bottom: monthly Brotogeris chiriri abundance, flower and fleshy fruit abundance, and percentage of feeding records $(\mathrm{N}=131)$, at the Miranda river gallery forest, from April 2000 to March 2002. 


\section{DISCUSSION}

\section{Resource abundance}

The Miranda river gallery forest is part of a vegetation mosaic, which includes deciduous and semi-deciduous habitats. While the number of tree species that produce fleshy or dry fruits is similar at the deciduous forest patches near the gallery forest (Araújo, 2001), my sample suggests a preponderance of species with fleshy fruits at the gallery forest. Most importantly, trees that produce fleshy fruits dominated in the phenology sample. Thus, this gallery forest is apparently an important source of fleshy fruits in the highly seasonal Pantanal. Furthermore, the massive flowering of species such as Inga vera, also pointed to this forest as an extraordinary source of nectar during the later dry season, a period of marked fruit scarcity (Fig. 2).

In neotropical dry forests massive flowering usually occurs between the later dry and early wet seasons, followed closely by fruit production (for a review, see van Schaik et al., 1993). At the Miranda river gallery forest, the major annual flowering peak matches this pattern, and arises mainly from species that produced fleshy fruits during the rainy season. Annually, such pronounced flowering occurred when the river level was lowest (pers. obs.), hence the dry conditions could contribute to triggering this phenophase, as happened at a gallery forest studied elsewhere (Kinnaird, 1992). The least prominent flower production during the middle dry season mainly included an abundant species with dry fruits and winged seeds (Tabebuia heptaphylla), which fruited when winds were stronger (AugustSeptember), and Ocotea diospyrifolia, whose fleshy fruits were delayed in developing, and ripened during the middle wet season together with other species that fruited during this period.

The conspicuous fruiting peaks presumably resulted from the influence of distinct environmental factors on two tree species groups. The pronounced fruiting peak in the middle wet season followed a typical fruiting pattern related directly to rainfall seasonality, as found for other neotropical semideciduous forests (Frankie et al., 1974; Bullock \& Solis-Magallanes, 1990; Peres, 1994). During the rainy season fleshy fruits predominated in the Miranda river gallery forest. However, a marked fleshy fruit production during the wet season is typical for tropical dry forests (Frankie et al., 1974; van Schaik et al., 1993). Apparently such a pattern is also usual for neotropical gallery forests within dry areas (Funch et al., 2002). The propensity for massive fleshy fruit production to occur most often during the early-middle rainy season is presumably related to the short period with wet conditions, in forests subjected to severe dry seasons. Both seed germination and seedling establishment usually take place just after the first heavy rainfall, thus avoiding unfavorable conditions and, consequently, a higher risk of mortality during the later wet season (van Schaik et al., 1993). In fact, only a few species (e.g., Genipa americana) bore fleshy fruits during the dry season at Miranda river gallery forest.

The other fruiting peak, more conspicuous if species with fleshy fruits are analyzed (Fig. 3), arose because of trees (mainly Banara arguta and Sapium obovatum) often exposed to floods for longer periods. Such species bore ripe fruits simultaneously with inundations, dropping a large number of diaspores into the water (pers. obs.). This fruiting pattern resembled those found for the Amazonian flood plain, in which a tree community fruiting peak coincides with forest inundation and most fruits are adapted to water or fish dispersal (Kubitzki \& Ziburski, 1994). Hence, for canopy frugivores at the Miranda river gallery forest massive food resources may be available annually, at least during three episodes influenced by distinct environmental factors.

\section{Parakeet and food resource abundance}

At the Miranda river gallery forest, occurrence of Brotogeris chiriri, as well as food resource production was variable. As this parakeet mainly foraged for massively produced resources, food was potentially the major cause for its abundance fluctuations. However, factors such as roosting and breeding could influence local parrot abundance (Casagrande \& Beissinger, 1997). Colonial breeding is not usual among parrots (Forshaw, 1989), but increased $B$. chiriri abundance during specific periods could result from gallery forest use as a breeding site. If this were so, I would probably have found an intense nesting activity simultaneously with major peaks of parakeet abundance. However, at the gallery forest I never found parakeets nesting (>2000 h of observations), a conspicuous and noisy activity among parrots mainly when caring for fledglings (del Hoyo et al., 1997). Furthermore, both in September 2000 and August 2001 parakeets were absent from the forest, but 30 days later their number sharply increased. Parakeets improbably selected 
nests, left eggs, brooded, and raised young in a very short period of time, since parakeet development is typically slow (Waltman \& Beisinger, 1992). Finally, nesting success is generally low among neotropical birds (Ricklefs, 1969; Skutch, 1976, 1985), hence parakeet abundance could hardly stem from the production of a large number of fledglings.

Communal roosting is usual among parrots (Forshaw, 1989), which in large numbers and with great commotion arrive to roost at dusk, and as conspicuously depart to foraging areas at dawn (Chapman et al., 1989; Casagrande \& Beisinger, 1997). When parakeets were abundant, I only observed them arriving in the gallery forest in small flocks to forage (mainly between 7:00 and 10:00 h), and never returning, for example, to a large crown at dusk, a typical parrot roosting behavior (Chapman et al., 1989; del Hoyo et al., 1997; Casagrande \& Besinger, 1997). In addition, when parakeets were abundant, during census work I recorded most of them from 7:00 to 8:00 h, a usual foraging period for parrots (Marsden, 1999). If parakeets roosted in the gallery forest, presumably most of them would be detected, from a few points at the beginning of census work, while departing for foraging areas.

Parrots are well known for wandering over large areas searching for food patches including abundant and ephemeral resources (Roth, 1984; Loiselle, 1988; Renton, 2001). At the Miranda river gallery forest, most food resources important for $B$. chiriri were available from later dry to the later wet season, when this parakeet was more abundant and often recorded foraging (Fig. 3). Some of these resources figured in a large proportion of the flowering and fruiting pattern. In addition, $B$. chiriri foraging activity to some extent coincided with the availability of its major food items. Thus, the consistent correspondence between $B$. chiriri abundance and the regular use of massive flower and fruit crops suggests that they periodically moved to the gallery forest in order to forage for variable resources (Renton, 2001; Wirminghaus et al., 2001, 2002). This was particularly evident in the case of Inga vera flowers, the most abundant resource, whose production every year coincided with major abundance peaks of $B$. chiriri, a large number of whom consumed its nectar.

In the neotropics, parakeets have only recently been recorded as using nectar intensively, and consequently pollinating some tree species, suggesting that nectar is an important resource for these birds (Vicentini \& Fischer, 1999; Cotton, 2001; Ragusa-
Netto, 2002a). On the other hand, in Australia and South Asia many parakeet species rely mostly on nectar and pollinate several plant species (Cannon, 1984; Brown \& Hopkins, 1995). Brotogeris chiriri mainly used Inga vera nectar during the harsh period of the year when in the gallery forest the fleshy fruits of Genipa americana, almost the only resource available, were not used by parakeets (Fig. 3, Table 1). Birds and mammals, other than hummingbirds and nectarivorous bats, rely on massive flower crops during periods of general fruit scarcity (Terborgh, 1986). For such animals, the nectar can provide nutrients similar to those found in fruit pulp, which are poor in fats and proteins but useful during severe periods (Ferrari \& Strier, 1992). Parrots studied elsewhere in seasonal habitats also made substantial use of flowers during the dry season, a period of low fruit availability (Galetti, 1993; Wermundsen, 1997). Therefore, the pronounced use of nectar when fruits are usually scarce may be important for the persistent presence of $B$. chiriri in the highly seasonal Pantanal.

The fruits of Cecropia and Ficus have been widely found in the Brotogeris diet, which includes the pulp and small seeds (Janzen, 1981; Roth, 1984; Pizo et al., 1995; Galetti, 1997; Ragusa-Netto, 2002b). In the Atlantic forest during the wet season B. tirica was highly abundant and mostly foraged for Cecropia glaziovii fruits in spite of the usual fruit availability during rains (Pizo et al., 1995). In the gallery forest during January 2001 and February 2002, B. chiriri foraged almost exclusively for the fruit of Cecropia pachystachya when these trees bore very large crops. Presumably, the availability of such crops together with the combined nutritional value (although not assessed) of pulp and seeds made these fruits one of the major food items for $B$. chiriri. Another important resource whose availability occurred simultaneously with major peaks of $B$. chiriri abundance (mainly in March 2002) was Inga vera fruits. Although Ing a fruits have been largely found in the diet of some neotropical parrots (Roth, 1984; Galetti, 1993), this has not been the case with the genus Brotogeris (del Hoyo et al., 1997). Nevertheless, B. chiriri has also been found consuming intensively Inga laurina arils in the cerrado (pers. obs.). Hence, the sweet, soft Inga arils are apparently among the valuable food items for $B$. chiriri over a large portion of its range.

Parrots often consume the pulp or endosperm of palm fruits, which may be the major food item for some macaws (Roth, 1984; Forshaw, 1989; del Hoyo et al., 1997). When they find palm fruits, 
neotropical parakeets usually eat the pulp, but few studies have reported the use of this food item (Pizo et al., 1995; Galetti, 1997). Brotogeris chiriri foraged for palm fruits mainly during the middle dry season, when the fleshy fruit supply was in decline (Fig. 3). The use of asynchronous resources, such as palm fruits, is assumed to represent an important dietary shift related to persisting frugivorous preferences in the face of the annual severely reduced fruiting that characterizes the dry season (Terborgh, 1986). Although Copernicia alba exhibited a synchronous fruiting pattern, its fruits were available during the early to the middle dry season, while Attalea phalerata bore fruits most of the time. Hence, these fruits were unimportant in the massive fruiting during the rains, a pattern which might perhaps explain the strong inconsistency between $B$. chiriri foraging activity and its abundance during May 2001.

This study points out the effect of massive food resources on the dynamic of an abundant parakeet in the South Pantanal. The results suggest a population movement within a vegetation mosaic towards abundant and ephemeral resources produced in a gallery forest. It also indicates some resources, such as Inga vera nectar, as being important food items for B. chiriri during harsh periods. Further long-term, and multi-habitat studies in the highly seasonal Pantanal will improve our knowledge of the effect of flower and fruit seasonality on parrot populations, which wander over large and diverse areas that include asynchronous patches of resources.

Acknowledgements - I am grateful to Alan Fecchio, Gesner Batista Ramos, Jacqueline Vasquez, André Silveira, and Cláudia Bitencourt for field assistance. Edilson, Rosemar, Rosana, and Josefa provided logistical support at BEP/UFMS. I thank Rosilene Rodrigues-Silva for assistance in identifying some plant species. Financial support was provided by FUNDECT and PROPP/ UFMS.

\section{REFERENCES}

ARAÚJO, A. C., 2001, Flora, fenologia de floração e síndromes de polinização em capões do Pantanal sul mato-grossense. Ph.D Dissertaton, Unicamp.

BROWN, E. D. \& HOPKINS, J. C., 1995, A test of pollinator specificity and morphological convergence between nectarivorous birds and rainforest tree flowers in New Guinea. Oecologia, 103: 89-100.

BULLOCK, S. H. \& SOLIS-MAGALLANES, J. A., 1990, Phenology of canopy trees of a tropical deciduous forest in Mexico. Biotropica, 22: 22-35.
CANNON, C. E., 1984, The diet of lorikeets Trichoglossus spp. in the Queensland-New South Wales border region. Еmu, 84: $16-22$.

CASAGRANDE, D. G. \& BEISSINGER, S. R., 1997, Evaluation of four methods for estimating parrot population size. Condor, 99: 445-457.

CHAPMAN, C. A., CHAPMAN, L. J. \& LEFEBVRE, L., 1989, Variability in parrot flock size: possible function of communal roosts. Condor, 91: 842-847.

COTTON, P. A., 2001, The behavior and interactions of birds visiting Erythrina fusca flowers in the Colombian Amazon. Biotropica, 33: 662-669.

DEL HOYO, J., ELLIOT, A. \& SARDATAL, J., 1997, Handbook of the birds of the world, Vol. 4. Sangrouse to Cuckoos. Lynx, Barcelona.

FERRARI, S. F. \& STRIER, K. B., 1992, Exploitation of Mabea fistulifera nectar by marmosets (Callitrix flaviceps) and muriquis (Brachyteles arachnoides) in south-east Brazil. J. Trop. Ecol., 8: 225-239.

FORSHAW, J. M., 1989, Parrots of the world. $3^{\text {rd }}$ ed. Lansdowne Editions, Melbourne.

FOURNIER, L. A., 1974, Un método cuantitativo para la medición de características fenológicas en árboles. Turrialba, 24: 422-423.

FRANCISCO, M. R., LUNARDI, V. O. \& GALETTI, M., 2002, Massive seed predation of Pseudobombax grandiflorum (Bombacaceae) by parakeets Brotogeris versicolurus (Psittacidae) in a forest fragment in Brazil. Biotropica, 34: 613-615.

FRANKIE, G. W., BAKER, H. G. \& OPLER, P. A., 1974, Comparative phenological studies of trees in tropical wet and dry forests in the lowlands of Costa Rica. J. Ecol., 62: 881-919.

FUNCH, L. S., FUNCH, R. \& BARROSO, G. M., 2002, Phenology of gallery and montane forest in the Chapada Diamantina, Bahia, Brazil. Biotropica, 34: 40-50.

GALETTI, M., 1993, Diet of scaly-headed parrot (Pionus maximiliani) in a semi-deciduous forest in southeastern Brazil. Biotropica, 25: 419-425.

GALETTI, M., 1997, Seasonal abundance and feeding ecology of parrots and parakeets in a lowland Atlantic Forest Brazil. Ararajuba, 5: 115-126.

GILARD, J. D. \& MUNN, C. A., 1998, Patterns of activity, flocking, and habitat use in parrots of the Peruvian Amazon. Condor, 100: 641-653.

HEJL, S. J., VERNER, J. \& BELL, W., 1990, Sequential versus initial observations in studies of avian foraging. Stud. Av. Biol., 13: 166-173.

JANZEN, D., 1981, Ficus ovalis seed predation by Orangeparakeet (Brotogeris jugularis) in Costa Rica. Auk, 98: 841844.

KINNAIRD, M. F., 1992, Phenology of flowering and fruiting of East African riverine forest ecosystem. Biotropica, 24: 187-194. 
KUBITZKI, K. \& ZIBURSKI, A., 1994, Seed dispersal in flood plain forest of Amazonia. Biotropica, 26: 30-43.

LOISELLE, B. A., 1988, Bird abundance and seasonality in a Costa Rican lowland forest canopy. Condor, 90: 761-772.

MARSDEN, S. J., 1999, Estimation of parrot and hornbill densities using a point count distance sampling method. Ibis, 141: 377-390.

OLIVEIRA-FILHO, A. T., RATTER, J. A. \& SHEPHERD, G. J., 1990, Floristic composition and community structure of a Brazilian gallery forest. Flora, 184: 103-117.

OLIVEIRA-FILHO, A. T., VILELA, E. A., CARVALHO, D. A. \& GAVILANES, M. L., 1994, Effects of soils and topography on the distribution of tree species in a tropical riverine forest in south-eastern Brazil. J. Trop. Ecol., 10: 483-508.

PERES, C. A., 1994, Primate responses to phenological changes in an Amazonian terra firme forest. Biotropica, 26: 98-112.

PIZO, M. A., SIMÃO, I. \& GALETTI, M., 1995, Diet and flock size of sympatric parrots in the Atlantic Florest of Brazil. Orn. Neot., 6: 87-95.

POTT, A. \& POTT, V. J., 1994, Plantas do Pantanal. Embrapa, Brasília.

RAGUSA-NETTO, J., 2002a, Exploitation of Erythrina dominguesii Hassl. (Fabaceae) nectar by perching birds in a dry forest in Western Brazil. Braz. J. Biol., 62: 877-883.

RAGUSA-NETTO, J., 2002b, Fruiting phenology and consumption by birds in Ficus calyptroceras (Miq.) Miq. (Moraceae). Braz. J. Biol., 62: 339-346.

RENTON, K., 2001, Lilac-crowned parrot diet and food resource availability: resource tracking by a parrot seed predator. Condor, 103: 62-69.

RICKLEFS, R. E., 1969, An analysis of nesting mortality in birds. Smith. Contr. Zool., 9: 1-48.

ROTH, P., 1984, Repartição do habitat entre psitacídeos simpátricos no sul da Amazônia. Acta Amazonica, 14: 175221.
SICK, H., 1997, Ornitologia brasileira. Nova Fronteira, Rio de Janeiro, 912p.

SKUTCH, A. F., 1976, Parent birds and their young. Univ. Texas Press. Austin, Texas.

SKUTCH, A. F., 1985, Clutch size, nesting success, and predation on nests of neotropical birds, reviewed. Ornithol. Monogr., 36: $575-594$.

TERBORGH, J., 1986, Keystone plant resources in the tropical forest. In: M. Soule (ed.), Conservation biology. Sinauer, Sunderland, Massachussets.

VAN SCHAIK, C. P., TERBORGH, J. W. \& WRIGHT, S. J., 1993. The phenology of tropical forests, adaptive significance, and consequences for primary consumers. Ann. Rev. Ecol. Syst., 24: 353-377.

VICENTINI, A. \& FISCHER, E. A., 1999, Pollination of Moronobea coccinea (Clusiaceae) by the Golden-winged Parakeet in Central Amazonia. Biotropica, 31: 682-696.

WALTMAN, J. R. \& BEISSINGER, S. R., 1992, Breeding behavior of the Green-rumped parrotlet. Wilson Bull., 104: 65-84.

WERMUNDSEN, T., 1997, Seasonal changes in the diet of the pacific Parakeet Aratinga strenua in Nicaragua. Ibis, 139: 566-568.

WIRMINGHAUS, J. O., DOWNS, C. T., SYMES, C. T. \& PERRIN, M. R., 2001, Abundance and activity patterns of the Cape Parrot (Poicephalus robustus) in two afromontane forests in South Africa. African Zool., 36: 71-77.

WIRMINGHAUS, J. O., DOWNS, C. T., SYMES, C. T. \& PERRIN, M. R., 2002, Diet of the cape parrot, Poicephalus robustus, in Afromontane forrests in Kwazulu-Natal, South Africa. Ostrich, 73: 20-25. 